\title{
Az Emberi Jogok Európai Bírósága ítélkezési gyakorlatának hatása a magyar büntetőeljárási törvényre**
}

\author{
büntetőeljárás - EJEB - tisztességes eljárás - fegyverek egyenlősége - \\ előzetes letartóztatás - védelemhez való jog
}

Jelen tanulmány az Emberi Jogok Európai Bírósága (EJEB) legújabb magyar vonatkozású ítéleteit vizsgálja a büntető eljárásjoghoz kapcsolódóan. Előkérdésként felmerül, hogy miért szükséges az EJEB esetjogát és annak a hazai jogalkotásra és jogalkalmazásra gyakorolt hatását vizsgálni. Noha az EJEB ,jogosan tart igényt arra, hogy alakítólag hasson a tagállamok jogrendszereire”1, az „olykor számunkra szokatlan 'kontinentális esetjog' építőköveiként”' megjelenő strasbourgi döntések egyedi ügyekben születnek, és általános kötelező erővel nem rendelkeznek. A Bíróság mindig az elé terjesztett ügy egyedi körülményeit vizsgálja, és arról dönt, hogy a konkrét esetben sérültek-e az Emberi jogok és alapvető szabadságok védelméről szóló, Rómában, 1950. november 4-én kelt Egyezmény (a továbbiakban: Egyezmény) rendelkezései. Magát a nemzeti jogszabályt azonban az EJEB sohasem minősíti, azt in abstracto nem vizsgálja. Ezt azért szükséges leszögezni, mert már az Egyezmény Magyarország általi aláírásakor is nyilvánvaló volt, hogy lesznek konfliktusok az egyezményi rendelkezések és a belső jog között, figyelemmel a strasbourgi esetjog és a hazai bírósági gyakorlat eltéréseire. ${ }^{3} \mathrm{Az}$ EJEB döntéseinek figyelembevétele még az alkotmánybírósági gyakorlatban sem jelenti azt, hogy azok az Alkotmánybíróságra kötelezők lennének. A strasbourgi esetjog alkotmányos relevanciájával kapcsolatban a lényeg „nem az, hogy ki lehet-e erőszakolni egy választ arra a kérdésre, hogy van-e jogi természetü kötelezettsége az alkotmánybíróságoknak a strasbourgi joggyakorlat követésére, hanem annak tudomásulvétele, hogy e jogvédelmi szinttől

* Dr. Szabó Krisztián egyetemi docens, Debreceni Egyetem Állam- és Jogtudományi Kar Büntető Eljárásjogi Tanszék, szkrisztian21@gmail.com.

** A tanulmány az Igazságügyi Minisztérium által támogatott „A jogászképzés színvonalának emelését célzó programok" keretében valósult meg.

1 BÁRD Károly: Emberi jogok és büntető igazságszolgáltatás Európában. Magyar Hivatalos Közlönykiadó, Budapest, 2007, 15.

2 Тоттн Mihály: A magyar büntetőeljárás az Alkotmánybiróság és az európai emberi jogi itélkezés tükrében. KJK-KERSZÖV, Budapest, 2001, 11 [a továbbiakban: TótH (2001)].

3 Erröl részletesen lásd BÁNÁTI János: A védői és a terhelti jogok a strasbourgi joggyakorlat tükrében. In: Busch Béla-Belovics Ervin-Tóth Dóra (szerk.): Békés Imre Ünnepi Kötet. PPKE JÁK, Budapest, 2000, 18. 
lefelé történő eltérés az állam nemzetközi felelősségét idézi fel”. ${ }^{4}$ Az Egyezmény és a hozzá kapcsolódó bírósági gyakorlat az alapjogvédelemnek azt a minimumszintjét határozza meg, amelyet minden részes államnak biztosítania kell, a nemzeti jog azonban ettől eltérő, magasabb követelményrendszert is kialakíthat az emberi jogok védelmére. ${ }^{5}$ Ezzel összhangban az új büntetőeljárási törvényröl szóló T/13972. számú törvényjavaslat (a továbbiakban: Törvényjavaslat) általános indokolásának II. pontja leszögezi: „Az Alaptörvénynek, valamint Magyarország nemzetközi jogi és európai uniós tagságából eredő kötelezettségeinek való megfelelés nyilvánvalóan garanciális minimumot jelent."

A rendes bíróságok gyakorlatára vonatkozóan megállapítható, hogy a strasbourgi esetjog egyre inkább visszatükröződik a bíróságok ítéleteiben és a felsőbb bíróságok útmutatásaiban. ${ }^{6}$ A számos pozitív példa ellenére azonban az EJEB-konform értelmezés követelménye a rendes bíróságok gyakorlatában közismerten nehezen honosodik meg, ${ }^{7}$ amit jól mutat az előzetes letartóztatás során a védelmet megillető iratismereti joggal kapcsolatos Nikolova-döntésben ${ }^{8}$ rögzített szempontok érvényesítése körüli számos nehézség. ${ }^{9}$ A jelenséget igazolja az ÍH 2014.53. számú döntés következő rendelkezése is: „Nem fogadható el a törvényszék azon indokolása, hogy az Emberi Jogok Európai Bírósága által hozott határozatokra csak annyiban lehet hivatkozni, és azok annyiban alkalmazandóak, amennyiben a Be. normaszövegében is megjelennek. Éppen az alapjogokkal kapcsolatosan kell különös gonddal ügyelni a strasbourgi joggyakorlat dinamikus jogértelmezésére, arra, hogy az egyes marasztaló határozatokból a megfelelö jogkövetkeztetést a joggyakorlat is levonja. "10 Ezzel kapcsolatban egyetértek Uitz Renátával abban, hogy bár az Alaptörvény 28. cikke „kifejezetten nem rendelkezik a nemzetközi jogi kötelezettségek, és így az emberi jogi kötelezettségek bírósági alkalmazásáról sem, az Alaptörvény nemzetközi és európai beágyazottságának következtében a jogszabályokat nehéz (és valószínüleg értelmetlen) az Alaptörvénnyel összhangban, de az EJEB gyakorlatának

4 KovÁcs Péter: Az Emberi Jogok Európai Bírósága ítéletére való hivatkozás újabb formulái és technikái a magyar Alkotmánybíróság, valamint néhány más alkotmánybíróság mai gyakorlatában. Alkotmánybírósági Szemle, 2013/2, 83-84.

5 4/2013. (II. 21.) AB határozat, $A B H ~ 2013,128$, 19. pont.

6 Uıтz Renáta: Nemzetközi emberi jogok és a magyar jogrend. In: Jakab András-Gajduschek György (szerk.): A magyar jogrendszer állapota. MTA TK JTI, Budapest, 2016, 200.

7 Kovács Kriszta: Az Emberi Jogok Európai Egyezménye és az uniós jog szerepe az alapjogi ítélkezésben. In: Somody Bernadette (szerk.): Alapjogi biráskodás - Alapjogok az ítélkezésben. L'Harmattan, Budapest, 2013, 159-160.

8 Nikolova kontra Bulgária ügy, 1999. március 25-i ítélet (ügyszám: 31195/96).

9 Erről részletesen lásd ELEK Balázs: A kényszerintézkedésekhez kapcsolódó iratmegismerési jog a nyomozás során. In: Elek Balázs-Fázsi László (szerk.): Az itélőmesterség dilemmái - Tanulmányok Dr. Remes Zoltán bíró emlékére. Printart-Press, Debrecen, 2015, 78-94; CsizmadiÁnÉ Dr. Pethö Tímea: Az előzetes letartóztatás gyakorlatának néhány aktuális kérdése - különös tekintettel a Nikolova döntés maradéktalan implementálására és a határozatok indokolására. Eljárásjogi Szemle, 2016/4, 3-8; RótH Erika: A tájékoztatáshoz való jog. In: Róth Erika (szerk.): Decem anni in Europaea Unione V. Miskolci Egyetemi Kiadó, Miskolc, 2016, 56-74; SzABó Krisztián: Iratismeret az előzetes letartóztatással kapcsolatban - eltérő jogalkalmazási tapasztalatok. Magyar Jog, 2016/3, 183-188.

10 Debreceni Ítélőtábla Bnyf.II.169/2014/2. 
figyelmen kívül hagyásával alkalmazni egy olyan jogrendszerben, ahol a nemzeti jogorvoslati lehetőségek kimeritése után a jogkereső fél útja az EJEB-hez vezet". ${ }^{11}$

A strasbourgi joggyakorlat vizsgálata tehát indokolt. Az alábbiakban összegzett kutatás során a 2013 és 2016 között született EJEB-ítéleteket vettem alapul, mivel ezek feldolgozása és a büntetőeljárásról szóló 1998. évi XIX. törvényre (Be.) gyakorolt hatásuk vizsgálata a hazai szakirodalomban csak részben történt meg. ${ }^{12}$ A kutatásnak különös aktualitást ad a folyamatban lévő büntetőeljárási kodifikáció is - írásomban a várható változásokra és a lehetséges jövőbeli problémákra is kitérek. A vizsgált időszakban a büntető eljárásjog területén a magyar vonatkozású ügyek körében elsősorban az elözetes letartóztatással, a hatékony védelemmel és a fogva tartás körülményeivel kapcsolatos döntésekkel találkozunk. Utóbbiakat jelen tanulmányban nem vizsgálom, mivel azok alapvetően a büntetés-végrehajtási jog területére tartoznak (bár az előzetes letartóztatás révén e kutatáshoz is kapcsolódhatnak).

\section{Az elözetes letartóztatással kapcsolatos határozatok}

Az előzetes letartóztatással kapcsolatban a strasbourgi ítéletek 2013 és 2016 között visszatérő jelleggel és gyakran szó szerint azonos indokolással a következök miatt marasztalták el Magyarországot:

1. az alternatív kényszerintézkedések alkalmazhatóságának érdemi vizsgálata sokszor hiányzik a döntéshozatal során;

2. az előzetes letartóztatási okokat megalapozó bizonyítékokhoz a hatóságok nem biztosítják a védelem hozzáférését;

3. a megalapozott feltevésen alapuló előzetes letartóztatási okok [Be. 129. § (2) bekezdés $b$ ), $c$ ) és $d$ ) pontja] gyakran megalapozatlanok;

4. a bírósági végzések nem kellően indokoltak, sztereotip jellegủek, általánosak.

\subsection{Az alternatív kényszerintézkedések alkalmazhatóságának érdemi vizsgálata}

A hatályos magyar jogszabályok és irányadó eseti döntések, továbbá a szakirodalom alapján az előzetes letartóztatással kapcsolatos döntéshozatal során magától értetődő annak vizsgálata, hogy enyhébb kényszerintézkedéssel elérhetők-e a büntetőeljárási célok. A határozatok indokolásának szükségszerüen ki kellene tér-

11 Uitz: i. m., 203.

$12 \mathrm{Az}$ ezt megelőző időszak vonatkozásában a témakör feldolgozásával kapcsolatban lásd KÁDÁR András Kristóf-KIRs Eszter-Lukovics Adél-Moldova Zsófia-M. Tо́тн Balázs: Az Emberi Jogok Európai Bíróságának előzetes letartóztatással kapcsolatos gyakorlata. Kézikönyv birák számára. Magyar Helsinki Bizottság, Budapest, 2014; Az előzetes letartóztatás gyakorlata: Az alternatív kényszerintézkedések és a bírói döntéshozatal vizsgálata. Kutatási jelentés, Magyar Helsinki Bizottság, 2015. október, http://www.helsinki.hu/ wp-content/uploads/MHB_kutatasi_jelentes_elozetes_letartoztatas_2015.pdf (2017. 05. 01.). 
nie arra, hogy van-e, vagy miért nincs lehetőség ezek alkalmazására. ${ }^{13} \mathrm{Az}$ érintett személy alkotmányos jogait korlátozó kényszerintézkedés elrendelésének (így az előzetes letartóztatásnak) a törvényi feltételek fennállása esetében is csak akkor van helye, ha az eljárás célja kisebb korlátozással járó más cselekménnyel (például házi őrizet, lakhelyelhagyási tilalom, óvadék) nem biztosítható. ${ }^{14} \mathrm{Az}$ EJEB ítéleteinek tükrében nem túlzás azt állítani, hogy hazánkban visszatérő problémát jelent ennek a követelménynek az érvényesítése. A vizsgált időszakban a Bíróság a következő esetekben állapította meg az Egyezmény 5. cikk 3. bekezdésének sérelmét:

$A z X$. Y. kontra Magyarország ügyben az EJEB azért marasztalta el hazánkat, mert a kérelmező több mint hat hónapig tartó előzetes letartóztatása során egyetlen bírósági végzés sem tette valódi megfontolás tárgyává más, enyhébb kényszerintézkedés alkalmazását. ${ }^{15}$ Ezt különösen annak fényében ítélte alapjogsértőnek a Bíróság, hogy az eljáró hatóságok mintegy két és fél hónap elteltével már tisztában voltak a kérelmező súlyos pszichés problémáival, amelyek vonatkozásában szakvélemény is rendelkezésre állt. A kérelmező romló egészségi állapotára tekintettel fogva tartása már nem szolgálta az észszerű időn belül történő bíróság elé állítás célját, tehát nem volt szükségesnek tekinthető. ${ }^{16} \mathrm{Az} A$. B. kontra Magyarország ügyben az EJEB szintén azt állapította meg, hogy az eljáró magyar hatóságok „csekély érdeklődést” mutattak a kevésbé szigorú kényszerintézkedések megfontolására, és ismétlődően elutasították a kérelmező óvadék iránti kérelmeit. A Bíróság hangsúlyozta, hogy az eljáró hatóságoknak kötelessége az előzetes letartóztatás időtartamát a lehető legrövidebb időszakra korlátozni, és megvizsgálni a kevésbé szigorú alternatívák alkalmazásának lehetőségét. ${ }^{17}$ A Bandur kontra Magyarország ügyben szintén megállapítást nyert, hogy az eljáró hatóságok elmulasztották az alternatív kényszerintézkedések alkalmazásának vizsgálatát, ráadásul úgy, hogy a mintegy három hónapos előzetes letartóztatás indokaként nem hivatkoztak valódi, konkrét tényekre. ${ }^{18}$

A Gál kontra Magyarország ügyben az EJEB szerint a magyar hatóságok nem indokolták meg, hogy a kérelmező több mint hároméves előzetes letartóztatása alatt miért nem alkalmaztak az előzetes letartóztatásnál kevésbé szigorú kényszerintézkedést, még az esetleges szökés és elrejtőzés veszélyére figyelemmel sem. A Fővárosi Bíróság (ma Fővárosi Törvényszék) a 100000000 Ft összegủ óvadék meghatározásakor nem igazán tett erőfeszítést annak megállapítására, hogy az adott

13 A Kúria Bpkf.I.486/2014/2. számon meghozott döntésére figyelemmel részletesen lásd ELEK Balázs: Az előzetes letartóztatás indokolása az Európai Emberi Jogi Bíróság gyakorlatának tükrében. Büntetőjogi Szemle, 2015/3, 39 [a továbbiakban: ELEK (2015)].

14 Ezzel összefüggésben lásd: Be. 60. § (2) bekezdése, Polgári és Politikai Jogok Nemzetközi Egyezségokmánya 9. cikke és 14. cikk 2. pontja, az Emberi jogok és alapvető szabadságok védelméről szóló Egyezmény 5. cikke és 6. cikkének 2. pontja, az Európa Tanács Miniszteri Bizottságának R (80) 11. számú Ajánlásának 9. pontja, a Kúria 99. büntető kollégiumi véleménye.

15 Ugyanezt állapította meg az EJEB az alábbi ügyekben: Hagyó kontra Magyarország ügy, 2013. április 23-i ítélet (ügyszám: 52624/10), 58. pont; Hunvald kontra Magyarország ügy, 2013. december 10-i ítélet (ügyszám: 68435/10), 42. pont; Nagy Gábor kontra Magyarország ügy, 2014. február 11-i ítélet (ügyszám: 33529/11).

16 X. Y. kontra Magyarország ügy, 2013. március 19-i ítélet (ügyszám: 43888/08), 40-41. pont.

17 A. B. kontra Magyarország ügy, 2013. április 16-i ítélet (ügyszám: 33292/09), 28. pont.

18 Bandur kontra Magyarország ügy, 2016. július 5-i ítélet (ügyszám: 50130/12), 67. pont. 
körülmények között mi minősülne megfelelő óvadékösszegnek. Továbbá a házi őrizetet elrendelő határozatot visszavonó döntést komoly indokkal kellett volna alátámasztani, ám ilyet még a Kormány sem tudott felhozni az eljárásban. ${ }^{19}$

Amint látható, a strasbourgi marasztalások alapvetően azt róják a bíróságok terhére, hogy nem tették valódi, érdemi megfontolás tárgyává az enyhébb kényszerintézkedések alkalmazásának lehetőségét. Egyes empirikus kutatások szerint az elérhető alternatív kényszerintézkedések ritka alkalmazásának egyik oka, hogy a hatóságok kevéssé bíznak ezek hatékonyságában. ${ }^{20} \mathrm{Ez}$ tükröződik például a Kúria BH 2014.268. számú döntésében, amelynek értelmében az elektronikus nyomkövető eszköz alkalmazása a szökés vagy elrejtőzés veszélyét nem küszöböli ki, csupán a hatékony rendőri ellenőrzés lehetőségét biztosítja. A BH 2017.2.46. számú döntés pedig már egyfajta tendenciaként rögzíti, hogy „több esetben bebizonyosodott: a nyomkövetö technikai eszköz alkalmazása ellenére egyes vádlottak kibújtak a kényszerintézkedés alól". Ezzel összhangban magam is úgy vélem, hogy a házi örizet, a lakhelyelhagyási tilalom vagy az óvadék elvetése kellö körültekintés és megfelelő indokolás mellett természetesen lehetséges, de ehhez a konkrét tényekre való hivatkozás elengedhetetlen. Az EJEB esetjoga alapján egyértelmű, hogy az állam terhére esik annak bizonyítása, miszerint a fogva tartással elérni kívánt cél kevésbé korlátozó intézkedéssel nem volt elérhető. Adott esetben a bizonyítási eljárás meghiúsítását vagy megnehezítését, a bizonyítékok és a tanúk befolyásolásának veszélyét a házi őrizet vagy a lakhelyelhagyási tilalom nem képes kizárni, ${ }^{21}$ de ilyenkor szükséges, hogy egyértelmű adatok álljanak rendelkezésre a terhelt ez irányú magatartásával kapcsolatban, és ezekről a bíróság döntésében számot adjon. Ma is megfontolásra érdemesnek tartom Tóth Mihály azon javaslatát, miszerint alternatív szankciók kiszabásának lehetősége esetén az előzetes letartóztatás alkalmazása legyen korlátozható, vagy a kényszerintézkedés általános feltételét meghatározott súlyú szabadságvesztéshez, a magam részéről hozzáteszem: meghatározott jellegü bủncselekményhez kösse a jogalkotó. ${ }^{22}$

\subsection{Az előzetes letartóztatást megalapozó bizonyítékok védelem részére történő hozzáférhetővé tétele}

Az EJEB már 1999-ben a Nikolova kontra Bulgária ügyben kimondta, hogy a fegyverek egyenlősége nem biztosított akkor, ha a védő nem férhet hozzá azon nyomozási iratokhoz, amelyek alapján ügyfele fogva tartásának jogszerüségét vitatni tudná. ${ }^{23}$ Ezt a megállapítást az Alkotmánybíróság 166/2011. (XII. 20.) AB határozata is megerősítette. ${ }^{24}$ Hazánkban csak másfél évtizeddel (!) a Nikolova-döntést követö-

19 Gál kontra Magyarország ügy, 2014. március11-i ítélet (ügyszám: 62631/11), 45-48. pont.

20 Az előzetes letartóztatás gyakorlata, i. m., 8.

21 Erröl részletesen lásd ELEK (2015): i. m., 40.

22 То́тн (2001): i. m., 239.

23 Nikolova kontra Bulgária ügyben hozott ítélet, 58. pont.

24 ABH 2011, 545, III. 4. pont: „Ha a nyomozási bíró bizonyos anyagokba a védőt nem engedi betekinteni, az a habeas corpus eljárásokban más szempontból is sértheti az Egyezmény követelményeit. Ahogyan arra a 
en vált biztosítottá az iratismeret és ennek révén az érdemi védekezés lehetősége a terhelt és védője számára az előzetes letartóztatásos döntésekkel kapcsolatban. Ezt az előrelépést azonban elsősorban nem az EJEB említett döntése, illetve a Magyarországot érintő sorozatos marasztaló ítéletek váltották ki, hanem az Európai Parlament és a Tanács 2012/13/EU irányelve a büntetőeljárás során a tájékoztatáshoz való jogról (a továbbiakban: Irányelv). ${ }^{25}$ Ennek 7. cikk (1) bekezdése kimondja: ha valakit a büntetőeljárás során fogva tartanak, az illetékes hatóság birtokában lévő azon iratokat, amelyek a fogva tartás jogszerüségének felülvizsgálatához szükségesek, a terhelt vagy védője rendelkezésére kell bocsátani. Az Irányelv rendelkezéseit a tagállamoknak 2014. június 2-áig kellett nemzeti jogukba átültetniük. Hazánkban 2014. január 1-jei hatállyal a jogalkotó akként módosította a Be. 211. § (1) bekezdését, hogy amennyiben az ügyészi indítvány tárgya előzetes letartóztatás elrendelése, úgy a gyanúsítottnak és a védőnek megküldött indítványhoz csatolni kell azoknak a nyomozási iratoknak a másolatát, amelyekre az indítványt alapozzák.

A joggyakorlat azonban az említett rendelkezést az értelmezési szintek legalacsonyabb fokán álló nyelvtani értelmezés alapján kizárólag az elrendelés esetében biztosította, a fenntartás körében nem. Pedig az EJEB irányadó gyakorlatára tekintettel egyértelműnek tűnt, amit a Debreceni Ítélőtábla Bnyf.II.169/2014/2. számon hozott végzésében, később ÍH 2014.53. számon közzétett eseti döntésében kifejtett, miszerint a védelemnek nemcsak az előzetes letartóztatás elrendelésekor, hanem annak fenntartásakor is meg kell ismernie az előzetes letartóztatási okokat tartalmazó iratokat. Ezt a jogosultságot azonban az ügyészségek és az alsóbb fokú bíróságok figyelmen kívül hagyták. ${ }^{26} \mathrm{~A}$ Kúria Összefoglaló véleménye ${ }^{27}$ ezért szorgalmazta az Irányelv átültetésének mielőbbi korrigálását. A jogalkotó ennek szükségességét elismerve a 2015. évi LXXVI. törvénnyel új rendelkezést iktatott be. A Be. 211. § (1a) bekezdése 2015. július 1-től ekként rendelkezik: „Ha az indítvány tárgya előzetes letartóztatás elrendelése, a gyanúsítottnak és a védőnek megküldött indítványhoz csatolni kell azoknak a nyomozási iratoknak a másolatát, amelyekre az indítványt alapozzák. Ha az indítvány tárgya az előzetes letartóztatás meghosszabbítása, a gyanúsítottnak és a védőnek megküldött indítványhoz csatolni kell azoknak az indítványt megalapozó nyomozási iratoknak a másolatát, amelyek az előzetes letartóztatás tárgyában hozott legutóbbi döntést követően keletkeztek." Ez a jogszabályhely immár nem ad lehetőséget eltérő értelmezésre: előzetes letartóztatás elrendelése és fenntartása körében is jogosult a védelem az iratismeretre, ekként pedig végre lehetősége nyílik a valódi és hatékony védekezés kifejtésére.

Bíróság a Nikolova kontra Bulgária ügyben 1999. március 25-én hozott ítéletében összefoglalóan rámutatott: Nem lehet szó a fegyverek egyenlöségéröl akkor, amikor egy ügyvéd nem tekinthet bele a nyomozási dossziénak azokba a dokumentumaiba, amelyek vizsgálata elengedhetetlen abból a szempontból, hogy hatékonyan vitathassa védence fogvatartásának jogszerüségét."

25 HL L 142, 2012. 06. 01., 1-10.

26 Részletesen elemzi SzaBó: i. m., 183-188.

27 Védői jogok a bírósági eljárásban - Összefoglaló vélemény. Kúria Büntető Kollégium Joggyakorlat-elemző csoport, 2014.EL.II.E.1/10.VÉDÖ-50.szám, http://www.kuria-birosag.hu/sites/default/files/joggyak/elfogadott_osszegzo_velemeny.pdf (2017. 05. 01.). 
A vázolt nehézségek miatt mindenképpen hasznos, ha áttekintjük a vizsgált idöszakban született, Magyarországot gyakorlatilag szó szerint azonos indokolással marasztaló határozatokat:

Az X. Y. kontra Magyarország ügyben az EJEB azért marasztalta el hazánkat, mert nem biztosított megfelelő hozzáférést a kérelmező számára az előzetes letartóztatással kapcsolatos döntések alkalmával a büntetöügy irataihoz. Az ítélet kimondta, hogy ezzel sérült a fegyveregyenlőség elve. Magyarország védekezésében érthetetlen módon arra hivatkozott, hogy a letartóztatás kérdésében döntö bíró is ugyanazokat az anyagokat kapja meg, mint a védelem. Az EJEB-nek kellett arra a köztudomású körülményre rámutatni, hogy nem a védelem és a bíróság között kell a fegyverek egyenlöségét biztosítani, hanem a terhelt és az ügyész között. Ez pedig nem biztosított, amennyiben a védelem nem ismerheti meg azokat a nyomozási iratokat, amelyek alapján hatékonyan vitathatja a terhelt fogva tartását. ${ }^{28}$

Az A. B. kontra Magyarország ügyben az EJEB szintén elmarasztalta hazánkat, mert nem biztosította a felek, azaz az ügyész és a terhelt közötti fegyveregyenlöséget, mivel a védőügyvédtől megtagadták azon nyomozási anyaghoz a hozzáférést, amely az előzetes letartóztatás törvényességének hatékony megtámadásához alapvető fontosságú lett volna. ${ }^{29}$ Ebben az ügyben a magyar állam arra hivatkozott, hogy az ügyész mérlegelési jogkörébe tartozik azoknak a nyomozási iratoknak a kiválasztása, amelyek tekintetében hozzáférést biztosít a védelemnek, és a letartóztatás kérdésében döntő bíró is ugyanezeket kapja meg. ${ }^{30} \mathrm{Az}$ előző esettel azonos módon ezt az érvelést az EJEB természetesen nem fogadta el.

A Gál kontra Magyarország ügyben a hazai bíróságok rögzítették: „adat” merült fel arra vonatkozóan, hogy a kérelmező egy társával bizonyítékokat és terhelő dokumentumokat kíván eltüntetni. Az eljárásban azonban az „adat” egyszer sem került bemutatásra. Ezzel kapcsolatban az EJEB leszögezte, hogy a gyanúsítottal nem ismertetett elemekre történő bírósági hivatkozás aligha egyeztethető össze az önkényes szabadságtól megfosztással szemben megkövetelt fegyveregyenlöség elvével. ${ }^{31}$

A Süveges kontra Magyarország ügyben az eljáró magyar bíróság figyelembe vett egy olyan kézzel írott levelet is, amelyben a kérelmező szökési szándékára és megfélemlítő viselkedésére volt utalás, de ebbe a kérelmezőnek nem engedett betekintést, nehogy a kézírás alapján azonosíthassa az anonim okirat szerzőjét. Az EJEB ezzel kapcsolatban azt állapította meg, hogy mivel a levél íróját a védelem nem kérdezhette, így érdemben nem is vitathatta az álítások valóságtartalmát. A döntés meghozatalakor viszont a levélnek nem tulajdonítottak kizárólagos vagy döntő mértékben jelentőséget, és az ügyészi indítvány ellenére nem változtatták a kérelmező házi őrizetét előzetes letartóztatásra, így az EJEB ebben a vonatkozásban nem állapított meg egyezménysértést. ${ }^{32}$

${ }^{28}$ X. Y. kontra Magyarország ügyben hozott ítélet, 48., 50. és 52. pont.

29 Ugyanezt állapította meg az EJEB az alábbi ügyekben: Hagyó kontra Magyarország ügyben hozott itélet, 17. pont; Baksza kontra Magyarország ügy, 2013. április 23-i ítélet (ügyszám: 59196/08), 47. pont; Galambos kontra Magyarország ügy, 2015. július 21-i ítélet (ügyszám: 13312/12), 31. pont; Bandur kontra Magyarország ügyben hozott ítélet, 79. pont.

30 A. B. kontra Magyarország ügyben hozott ítélet, 34., 36. és 39. pont.

31 Gál kontra Magyarország ügyben hozott ítélet, 42. pont.

32 Süveges kontra Magyarország ügy, 2016. május 2-i ítélet (ügyszám: 50255/12), 110-116. pont. 
Ahogy az a vizsgált esetekből is egyértelműen megállapítható, a fegyverek egyenlőségéből következő iratismeret biztosításával huzamosabb időn keresztül probléma volt hazánkban, dacára az EJEB marasztaló döntéseinek és az Alkotmánybíróság határozatainak. Holott az Alkotmánybíróság már a Nikolova-döntést megelőzően, a 6/1998. (III. 11.) AB határozatában kifejtette, hogy a fegyveregyenlőség kettős feltétele egyrészt a felek mindegyikének személyes jelenléte az eljárási cselekmények során, másfelöl az ügyben releváns adatok vád és védelem részéröl ugyanolyan teljességben és mélységben történő megismerésének lehetősége. ${ }^{33} \mathrm{~A}$ határozat egyértelműen rögzítette, hogy a fegyverek egyenlősége a büntetőeljárásban azt biztosítja, hogy a vádnak és a védelemnek egyenlő esélye és alkalma legyen állást foglalni tény- és jogkérdésekben. ${ }^{34}$ Erre tekintettel érthetetlen az idézett strasbourgi ügyekben a Kormány azon hivatkozása, miszerint a fegyveregyenlőség a védelem és a bíróság (!) között biztosított volt.

A jövőre nézve rendkívül fontosnak tartom, hogy az új büntetőeljárási törvény egyértelmű rendelkezéseket tartalmazzon már a nyelvtani értelmezés szintjén is. Ezért örvendetes, hogy a Be. tervezet ${ }^{35} 463$. §-a és ezzel azonosan a Törvényjavaslat 470. §-a maradéktalanul biztosítja az iratismeretet a védelem számára. ${ }^{36}$ Azért is különösen üdvözlendő ez a megoldás, mert az iratismeret biztosításával párhuzamosan az elrendelt előzetes letartóztatások száma csökkent: míg ez 2013-ban, a Be. módosítást megelőző utolsó évben 6098 volt 91,3\%-os ügyészi eredményesség mellett, addig 2014-ben 4836-ra csökkent (90,9\%-os ügyészi eredményesség mellett), 2015-ben pedig tovább mérséklődött 4453-ra (87,7\%-os ügyészi eredményesség mellett). ${ }^{37} \mathrm{Ez}$ a tendencia egyrészről az előzetes letartóztatásos eljárások érdemibbé válásával magyarázható, másfelől pedig azzal, hogy az ügyészség nyomozástaktikai megfontolásokból bizonyos esetekben indítványt sem tesz a legsúlyosabb kényszerintézkedésre, így kerülve el azt, hogy a nyomozási iratok egy részét ki kelljen adnia a védelemnek. ${ }^{38} \mathrm{~A}$ kedvező irányú változásokra figyelemmel nem tudok

33 Erröl részletesen lásd GÁcsı Anett Erzsébet: A fegyverek egyenlösége elv összetett vizsgálata a (hatékony) védelemhez való jog és a bizonyítékok értékelése mátrixában. In: Gál Andor-Karsai Krisztina (szerk.): $A d$ valorem: Ünnepi tanulmányok Vida Mihály 80. születésnapjára. lurisperitus Bt., Szeged, 2016, 76-77 és ELEK Balázs: Habeas corpus a magyar büntetőeljárásban. Európai Jog, 2015/6, 26-27.

34 ABH 1998, 91, II. 5. pont.

35 Az Igazságügyi Minisztérium 2016 júniusában nyilvánosságra hozott előterjesztése az új büntetőeljárási törvényről.

36 A Be. tervezet 463. §-a és a Törvényjavaslat 470. §-a azonosan:

„(1) Ha az indítvány tárgya letartóztatás vagy előzetes kényszergyógykezelés elrendelése, az indítvány megküldését követően a gyanúsított és a védő számára biztosítani kell azoknak az ügyiratoknak a megismerését, amelyekre az indítványban hivatkoznak.

(2) Ha az indítvány tárgya a letartóztatás meghosszabbítása, az indítvány megküldését követően a gyanúsított és a védő számára biztosítani kell azoknak az ügyiratoknak a megismerését is, amelyekre az indítványban hivatkoznak és amelyek a letartóztatás tárgyában hozott legutóbbi döntést követően keletkeztek.

(3) Az ügyészség az (1) és (2) bekezdésben meghatározott ügyiratok megismerését a védekezésre való felkészüléshez szükséges időben és módon - legkésőbb az ülés megkezdését megelőző egy órával - köteles a terhelt és a védő számára biztosítani. Az ügyészség az (1) és (2) bekezdésben foglaltak teljesítéséhez a nyomozó hatóságot is igénybe veheti."

37 Ügyészségi Statisztikai Tájékoztató (Büntetőjogi Szakterület). Legföbb Ügyészség, Budapest, 2016, http:// ugyeszseg.hu/repository/mkudok8724.pdf, 48 (2017. 05. 01.).

38 Az előzetes letartóztatás gyakorlata, i. m., 41. 
egyetérteni a Fővárosi Ítélőtábla Büntető Kollégiumának 2/2014. (III.3.) BK véleményében foglaltakkal, miszerint nem akadálya az ülés megtartásának, ha az ügyészség nem bocsátotta a gyanúsított és a védő rendelkezésére a nyomozási iratoknak az indítványt megalapozó másolatát. A nyelvtani értelmezés szintjén helytálló a következtetés, hiszen erre vonatkozó szabály - sajnos - valóban nincs a törvényben, de ez gyakorlatilag kiüresíti az Irányelv, illetve a Be. vonatkozó rendelkezéseinek tartalmát, és tulajdonképpen egy jogellenes helyzetet szentesít. Indokolt lenne a törvényben rögzíteni, hogy az ügyész ezen mulasztása esetén az elözetes letartóztatás kérdésében való döntés előfeltétele hiányzik, így ülés nem tartható vagy érdemi határozat nem hozható.

\subsection{A Be. 129. § (2) bekezdés b) pontjában meghatározott előzetes letartóztatási ok}

Az ún. b) pontos előzetes letartóztatással kapcsolatban az EJEB magyar vonatkozású ítéletei alapján visszatérő probléma, hogy önmagában a megalapozott gyanú tárgyát képező büncselekmény kiemelt tárgyi súlya nem indokolhatná a legsúlyosabb kényszerintézkedés elrendelését vagy fenntartását. Sajnálatos tény, hogy „a büncselekmény súlyára való automatikus hivatkozás, a várható büntetés, mint a szökés vagy elrejtőzés veszélyét kizárólagosan megalapozó tényező, valamint a terhelt egyéni körülményeinek, illetve az alternatív kényszerintézkedések alkalmazhatósága vizsgálatának hiánya a magyar bírói gyakorlat sokat kritizált sajátosságai”. ${ }^{39}$ Ennek oka, ahogyan erre Herke Csongor rámutat, az lehet, hogy a Kúria (korábban Legfelsőbb Bíróság) korábbi eseti döntéseiböl ${ }^{40}$ olyan gyakorlat kristályosodott ki, miszerint a bủncselekmény tárgyi súlya, a kiszabható büntetés mértéke önmagában megalapozhatja az előzetes letartóztatás elrendelését. ${ }^{41}$ Későbbi eseti döntések, ${ }^{42}$ illetve a szakirodalom alapján viszont egyértelmű, hogy nem lehet kizárólag a várható büntetés súlyosságára hivatkozni, hanem figyelemmel kell lenni a terhelt személyiségére, lakóhelyére, jövedelmére, foglalkozására, családi kötődéseire, erkölcsiségére, az országhoz való kötődésére, ${ }^{43}$ életkorára, egészségügyi állapotára, szocializálódottságára. ${ }^{44} \mathrm{~A}$ bírói gyakorlat ,indokolt kritikájaként fogalmazható meg, hogy a szökés veszélyét a gyakorlatban sokszor mechanikusan állapítják meg bizonyos tárgyi súlyú büncselekmények esetében. Ezen inditványok - nemritkán - az el-

${ }^{39}$ A gyanú árnyékában - Kritikai elemzés a hatékony védelemhez való jog érvényesüléséról. Magyar Helsinki Bizottság, Budapest, 2009, http://helsinki.hu/wp-content/uploads/A-gyanu-arnyekaban-final.pdf, 38 (2017. 05. 01.).

40 BH 1996.578.; BH 1995.505.; FBK 1993/33.

41 HeRkE Csongor: A letartóztatás feltételei nemzetközi kitekintésben. In: Gál Andor-Karsai Krisztina (szerk.): Ad valorem: Ünnepi tanulmányok Vida Mihály 80. születésnapjára. lurisperitus Bt., Szeged, 2016, 149 [a továbbiakban: HERKE (2016)].

42 BH 2009.7.; BK LBI 2009/28.

43 EleK (2015): i. m., 41. és CZINE Ágnes-SzaBó Sándor-VILLÁNYI József: Strasbourgi itéletek a magyar büntetőeljárásban. HVG-ORAC, Budapest, 2008, 259.

$136{ }^{44}$ Bócz Endre: Személyes szabadság korlátozása a terhelt jelenlétének biztosítása érdekében. In: Gellér Balázs (szerk.): Békés Imre Ünnepi Kötet. ELTE ÁJK, Budapest, 2000, 50-51. 
járás adott szakaszában és a rendelkezésre álló nyomozati iratokban megtalálható információk alapján is csupán feltételezéseken alapulnak, méghozzá oly mértékben, hogy erre hivatkozással az előzetes letartóztatás tárgyalt különös oka érdemben nem állapitható meg." ${ }^{45}$ Egyes empirikus vizsgálati adatok azt mutatják, hogy kiemelkedően magas, $90 \%$ feletti arányban hivatkoznak az ügyészi indítványok a várható büntetés súlyára, ezt követi $40 \%$ körüli arányban az az érv, miszerint a terhelt munkanélküli, nincs bejelentett munkahelye. ${ }^{46}$

Pedig a Be. Magyarázata szerint „szó sem lehet puszta fikcióról, a következtetést tényekkel kell megalapozni, és azokról a kényszerintézkedés alkalmazásáról szóló végzésben számot is kell adni”. ${ }^{47}$ Ezt megerősíti a BH 2009.7. számú döntés is, amely szerint annak a következtetésnek, hogy fennáll a szökés, elrejtőzés veszélye, tényeken kell alapulnia. A BK LBI 2009/28. számú döntés ezzel összhangban rögzíti, hogy önmagában a büncselekmény tárgyi súlya nem alapozza meg a Be. 129. § (2) bekezdés $b$ ) pontja szerinti elözetes letartóztatási különös okot, hanem figyelemmel kell lenni a terhelt személyében rejlő kockázatokra is. A szökés veszélye általánosságban akkor áll fenn, ha bizonyos adatok alapján nagy a valószínüsége, hogy a terhelt kivonná magát a büntetőeljárás alól. A büncselekmény tárgyi súlya tehát ennek csak az egyik tényezője lehet, önmagában erre azonban az előzetes letartóztatás nem alapozható.

A vizsgált időszak magyar vonatkozású strasbourgi esetei egyértelmüen rámutatnak az ún. b) pontos előzetes letartóztatással kapcsolatban fennálló jogalkalmazási hiányosságokra:

Az A. B. kontra Magyarország ügyben az EJEB megállapította, hogy a magyar bíróságok ismétlődően a súlyos szankció kilátására figyelemmel fennálló szökés és elrejtőzés veszélyére hivatkoztak, de a vádak tárgyi súlyán kívül az eljárás egyetlen szakaszában sem hoztak fel érvet annak alátámasztására, hogy a kérelmező megszökhet vagy elrejtőzhet. A Bíróság ezt különösen arra tekintettel találta problémásnak, hogy a kérelmező maga jelentkezett a rendőrségen. ${ }^{48} \mathrm{~A}$ Baksza kontra Magyarország ügyben szintén megállapítást nyert, hogy a vádak tárgyi súlyán kívül a magyar bíróságok az eljárás egyetlen szakaszában sem hoztak fel érvet annak alátámasztására, hogy a kérelmező megszökhet vagy elrejtőzhet, amit az EJEB nem talált kielégítőnek annak fényében, hogy a majdnem két és fél évig fogva tartott kérelmező legális jövedelemmel rendelkezett, és több családtagot is eltartott. ${ }^{49}$

A Hagyó kontra Magyarország ügyben az EJEB megállapította, hogy az előzetes letartóztatás meghosszabbítása során minden bírósági szinten megismételt kockázatok fennállását a hatóságok szemében pusztán a vád tárgyi súlya, a várható ítélet súlyossága, valamint egy arra utaló adat támasztott alá, amely szerint a kérelmezönek szándékában állt a szökés és elrejtőzés, azonban ezt a bizonyítékelemet soha nem specifikálták és soha nem mutatták be a védelemnek. A döntés értelmében

45 Belovics Ervin-Tóth Mihály: Büntető eljárásjog. HVG-ORAC, Budapest, 2015, 167.

46 Az elözetes letartóztatás gyakorlata, i. m., 46.

47 Holé Katalin-Kadlót Erzsébet (szerk.): A büntetőeljárásról szóló 1998. évi XIX. törvény magyarázata, II. kötet. Magyar Hivatalos Közlönykiadó, Budapest, 2007, 506.

48 A. B. kontra Magyarország ügyben hozott ítélet, 25. pont.

49 Baksza kontra Magyarország ügyben hozott ítélet, 36. pont. 
a vádak súlyossága „releváns” szempont, de önmagában nem elégséges alap a teljes, azaz több mint kilenc hónapos időszakra terjedő fogva tartáshoz. ${ }^{50}$ Ugyanezt állapította meg a Bíróság a Hunvald kontra Magyarország ügyben a kérelmező harmincegy hónapos fogva tartása vonatkozásában. ${ }^{51}$ Utóbbi esetben a hatóságok hivatkoztak egy bizonyos, a kérelmező elrejtőzési szándékára utaló bizonyítási elemre is, ezt azonban soha nem nevesítették vagy fedték fel a védelem elött.

A Gál kontra Magyarország ügyben, megismételve az említett ítéletekben rögzítetteket, az EJEB észrevételezte azt is, hogy a magyar bíróságok által a $b$ ) pontos előzetes letartóztatást megalapozó azon hivatkozás, miszerint az állítólagosan elkövetett büncselekmények egy szerteágazó és potenciálisan az alvilághoz kapcsolódó tevékenység részét képezik, a tényleges helyzetre vonatkozó bizonyítható adatok hiányában a spekuláció határán mozog és nem felel meg a törvény szövegének, ezért aligha értelmezhető olyanként, mint ami a szökés és elrejtőzés veszélyét alátámasztaná. A testület kifogásolta továbbá, hogy a magyar bíróságok nem vették figyelembe a kérelmező szökését valószínütlenné tévő személyes körülményeket, így családi hátterét. ${ }^{52}$

A Galambos kontra Magyarország ügyben az EJEB megállapította, hogy a szökés, elrejtőzés veszélyére alapozott előzetes letartóztatás egy büntetlen előéletü, közel 60 éves, rendezett anyagi körülmények között élö, szoros családi kötelékkel rendelkező terhelt esetében nem alapozható pusztán arra a körülményre, hogy külföldi kapcsolatokkal rendelkezik. A külföldi kapcsolatok ténye bár „releváns” körülmény volt, de önmagában nem elégséges alap a teljes, azaz több mint kilenc hónapos időszakra terjedő fogva tartáshoz. Különösen igaz ez annak fényében, hogy az előzetes letartóztatást megelőzően tizennégy napig házi őrizetben lévő kérelmező ezen időszak alatt nem kísérelt meg szökést vagy elrejtőzést, és nem vette fel a kapcsolatot külföldi személyekkel, holott mindkettőt megtehette volna. ${ }^{53}$

A Süveges kontra Magyarország ügyben az EJEB megerősítette, hogy a szökés, elrejtőzés veszélyét minden esetben konkrét adatokkal kell igazolnia az eljáró hatóságoknak, figyelemmel a terhelt személyiségére, előéletére, foglalkozására, lakhatására, vagyoni helyzetére, családi kapcsolataira és azon országhoz való kötődésére, ahol az eljárást vele szemben folytatják.$^{54} \mathrm{~A}$ Bandur kontra Magyarország ügyben a Bíróság szintén azt állapította meg, hogy a kérelmező három hónapos előzetes letartóztatását érintően a bírósági döntések egyetlen konkrét adatot sem tartalmaztak a szökés, elrejtözés tekintetében, és nem vették figyelembe, hogy a büntetlen előéletű, negyven éve azonos lakcímen élő és családtagok eltartásáról gondoskodó kérelmező kamionsofőrként dolgozott, emiatt igazoltan nem tartózkodott Magyarországon, de önként jelentkezett a rendőrségen, amikor tudomást szerzett arról, hogy a hatóság ki kívánja hallgatni. ${ }^{55}$

50 Hagyó kontra Magyarország ügyben hozott ítélet, 8., 9. és 54. pont.

51 Hunvald kontra Magyarország ügyben hozott ítélet, 40. pont.

52 Gál kontra Magyarország ügyben hozott ítélet, 45. pont.

53 Galambos kontra Magyarország ügyben hozott ítélet, 6., 23. és 24. pont.

54 Süveges kontra Magyarország ügyben hozott ítélet, 92. pont.

55 Bandur kontra Magyarország ügyben hozott ítélet, 63. és 64. pont. 
A Nagy Gábor kontra Magyarország ügyben az EJEB azért hozott elmarasztaló döntést, mert a magyar hatóságok nem vették figyelembe a kérelmező szabadlábra helyezése mellett szóló érveket. Az ítélet rögzítette, hogy a szabadlábra helyezés melletti és elleni érvek nem lehetnek „általánosak és elvontak”. ${ }^{56}$

$A z$ ismertetett döntések egyértelmüen jelzik, hogy azon korábbi, és részben ma is élő bírói gyakorlat, miszerint a megalapozott gyanú tárgyát képező bűncselekmény tárgyi súlya önmagában megalapozhatja az előzetes letartóztatás elrendelését, már nem tartható fenn. Ennek ellenére a bírósági végzésekben igen gyakran megjelenik azon érv, hogy az eljárás tárgyát képező bűncselekmény törvényi fenyegetettsége önmagában is olyan mértékü, amely miatt megalapozottan feltehető a szökés, elrejtőzés veszélye, és így indokolt a b) pontos előzetes letartóztatás elrendelése. ${ }^{57} \mathrm{Kü-}$ lönösen annak fényében érthetetlen ez, hogy az EJEB töretlen ítélkezési gyakorlata ebben a kérdésben már az ezredfordulón ismert volt. ${ }^{58}$ Még napjainkban is megfontolandónak tartom Herke Csongor 2002-ben megfogalmazott javaslatát, miszerint szökés veszélye esetén „a döntés objektivitásának elősegítése érdekében bevezethető lenne az az osztrák rendelkezés, amely szerint azoknál a terhelteknél, akik belföldön állandó lakóhellyel és munkával rendelkeznek, feltéve, hogy a terhükre rótt büncselekmény legfeljebb 5 évi szabadságvesztéssel fenyegetett és intézetböl még nem szöktek meg, a szökés (elrejtőzés) veszélyét mindenképpen kizártnak kell tekinteni”, de természetesen 5 évnél súlyosabb szabadságvesztéssel fenyegetett büncselekmények esetében sem kötelező az elrendelés. ${ }^{59}$

\subsection{A Be. 129. § (2) bekezdés c) pontjában meghatározott előzetes letartóztatási ok}

Az előzetes letartóztatás ezen esetében az eljáró hatóságok szerint a terhelt a bizonyítást megnehezítené, tanúkat befolyásolna, okiratokat semmisítene meg, vagy más módon hiúsítaná meg a büntetőeljárás sikerét. Mivel ez általánosságban minden esetben feltételezhető a terheltről, ezért a kollúzió veszélyét tényekből levont következtetéseknek kell megalapozniuk. ${ }^{60}$ A legtöbbször azonban ezek a konkrét adatok nem állnak rendelkezésre, így komoly gyakorlati problémát jelent, hogy az ún. c) pontos előzetes letartóztatás nincs kellően megindokolva a bírósági végzésekben, általában a törvényszöveg egyszerü lemásolása és esetleg kifejtése történik meg. Viszont minden „olyan indokolás törvényellenes, amelyet bármely más esetre alkalmazni lehet, hiszen ilyenkor nem a terhelt letartóztatását indokolja a bíró, hanem azt fejti ki, hogy a Be. szerint mikor lehet helye letartóztatásnak" ${ }^{61}$

56 Nagy Gábor kontra Magyarország ügyben hozott ítélet, 31-32. és 21. pont.

57 ELEK (2015): i. m., 42.

58 Erről részletesen lásd Róth Erika: Az elítélés előtti fogvatartás dilemmái. Osiris, Budapest, 2000, 150.

59 HeRke Csongor: A letartóztatás. Dialóg Campus, Budapest-Pécs, 2002, 298 [a továbbiakban: HeRKE (2002)].

60 ELEK (2015): i. m., 46.

61 Herke (2016): i. m., 145. 
Sok esetben pusztán azért állapítja meg a kollúziós előzetes letartóztatási okot a bíróság, mert a nyomozás még nem fejeződött be, az folytatódik, több tanú, illetve több gyanúsított folytatólagos kihallgatására fog sor kerülni, vagy további személyek gyanúsítottá nyilvánítása várható. A helyes értelmezés szerint azonban ez önmagában még nem elégséges. Ahogy arra Herke Csongor helytállóan rámutat, a megfelelő indokoláshoz a bírónak két dolgot kell kifejtenie: mi utal arra, hogy a terhelt meg kívánja hiúsítani az eljárást, és az eset objektív körülményei lehetővé teszik-e ezt számára. ${ }^{62}$ Ezzel összhangban a BH 2007.41. számú döntés szerint törvénysértő az előzetes letartóztatás elrendelése, amennyiben a végzésben a megjelölt törvényi okok a ténybeli alapokat nélkülözik. Ha ugyanis nem merül fel konkrét adat arra vonatkozóan, hogy a gyanúsított szabadlábra kerülése esetén az eljárás sikerét meghiúsítaná vagy megnehezítené, úgy erre vonatkozó megalapozott feltevés nem alapítható. A Be. Magyarázata ezzel összhangban kiemeli, hogy a terhelt potenciális helyzete és képessége a bizonyítás befolyásolására önmagában még nem elégséges következtetési alap, ezen ok megállapításához szükséges valamely megtörtént tényre vagy cselekvési igyekezetre hivatkozni. ${ }^{63} \mathrm{~A} \mathrm{BH} 2006.280$. számú eseti döntésben foglaltak szerint is csak akkor rendelhető el a c) pontra alapított előzetes letartóztatás, amennyiben a tanúk terhelt részéröl történt megfenyegetésére adatok merülnek fel, s emiatt a bizonyítási eljárás folytatása veszélybe kerül. Kiemelendő továbbá a BH 2005.205. számú eseti döntés, amely szerint nem megalapozott a c) pontra történő hivatkozás, amennyiben az a rendelkezésre álló nyomozási iratokban szereplő információkat figyelembe véve is túlnyomó részben feltételezéseken alapul.

Mindezekre figyelemmel egyáltalán nem meglepő, hogy az EJEB vizsgált időszakban hozott határozatai pontosan a konkrét tények hiányát rótták fel a magyar bíróságoknak:

Az A. B. kontra Magyarország ügyben a magyar bíróságok ismétlődően hivatkoztak a kérelmezőnek a nyomozásba való, a tanúk befolyásolásával és megfélemlítésével történő beavatkozásának veszélyére. Indokolásaik a kérelmező és társai terhére rótt büncselekmények szervezett jellegén kívül azonban semmilyen ilyen veszélyre utaló konkrét elemet nem tartalmaztak. Nem volt elégséges az a tényadat sem, hogy az egyik tanú számára kibocsátott idézést az egyik terheltnél találták meg, mert nem derült ki, hogy ez maga a kérelmező volt-e, és ez az EJEB szemében olyan körülmény volt, amely még a tanúvédelem fontosságát emlékezetben tartva is csökkenti ezen megfontolás relevanciáját. A szervezett elkövetés vádjára hivatkozó érvelést pedig meglehetősen általánosnak találta az EJEB, amely nem elégséges a kérelmező elhúzódott tartamú, mintegy huszonhárom hónapos előzetes letartóztatásának indokoltságához. ${ }^{64}$ A Hunvald kontra Magyarország ügyben szintén az eljárás tárgyát képező büncselekmények szervezett jellege és az érintett pénzösszegek nagysága miatti kollúzió veszélyére alapozták az előzetes letartóztatást, anélkül hogy bármilyen elemzésbe bocsátkoztak volna ezeknek a feltétele-

62 HeRke (2016): i. m., 145.

63 Holé-Kadlót: i. m., 508.

64 A. B. kontra Magyarország ügyben hozott ítélet, 26. pont. 
zéseknek a ténybeli megalapozottságával kapcsolatban. Az EJEB megállapította, hogy ezek a sztereotip indokok nem elégségesek a kérelmező fogva tartásához. ${ }^{65}$

A Gál kontra Magyarország ügyben az EJEB azt rögzítette, hogy a vádemelést követő szakban az összejátszás veszélyét sokkal kevésbé kell relevánsnak tekinteni, mint a nyomozási szakaszban. ${ }^{66} \mathrm{E}$ döntés értelmében is lényeges szempont, hogy a kollúzió veszélye az eljárás elörehaladtával egyre inkább elenyészik, és ez az előzetes letartóztatási ok tűnik el legtöbbször az idő múlásával a bíróságok érveléséböl, különösen a vádirat benyújtása után. ${ }^{67}$ Megfontolásra érdemes lehet a német Büntető perrendtartás (StPO) azon megoldása is, amely bizonyos súlyú büncselekmények esetében eleve kizárja ezen okból az előzetes letartóztatást. ${ }^{68}$ Ezenkívül abban a gyakori esetben, amikor a c) pontos előzetes letartóztatás elrendelése vagy fenntartása csak arra hivatkozással történik, hogy további nyomozási cselekmények elvégzése szükséges, meg kellene követelni annak érdemi vizsgálatát, hogy ezeket a cselekményeket a terhelt ténylegesen tudja-e befolyásolni.

\subsection{A Be. 129. § (2) bekezdés d) pontjában meghatározott előzetes letartóztatási ok}

Az ún. d) pontos előzetes letartóztatás esetében az újabb szabadságvesztéssel büntetendő bűncselekmény elkövetésének objektív lehetőségét, illetve a terhelt ehhez való szubjektív viszonyulását kell vizsgálni. ${ }^{69}$ Ennek hiányában elvileg bárkinél feltételezhető lenne valamilyen bủncselekmény elkövetésének a veszélye. Az eljáró hatóságok ebben a körben túlnyomórészt a terhelt korábbi elítéléseire, ezzel összefüggésben életmódjára hivatkoznak.

Ezen letartóztatási ok tekintetében a vizsgált időszakban csupán egyetlen érdemi marasztalással találkozunk. A Nagy Gábor kontra Magyarország ügyben az EJEB megállapította, hogy a kérelmező elözetes letartóztatásával kapcsolatos végzések egy „standard formulán” alapultak, miszerint a fogva tartás indokolt, mert a kérelmezőnek nincs munkahelye, ezért újabb büncselekményeket követhet el. Az EJEB szerint a kérelmező büntetlen előéletére tekintettel a bíróságoknak kidolgozottabb indokolást kellett volna adniuk az előzetes letartóztatás fenntartásának igazolására. Az egyébként rendezett anyagi körülmények között élö, büntetlen elöéletủ kérelmező esetében pusztán a munkahely hiányából nem vonható le olyan következtetés, hogy hajlamos lenne újabb büncselekmény elkövetésére. ${ }^{70}$

A bűnismétlés veszélyével kapcsolatban egyetértek Herke Csongor azon javaslatával, miszerint „a magyar Be. tág értelmezése helyett indokolt lenne csak hasonló

65 Hunvald kontra Magyarország ügyben hozott ítélet, 39., 40. és 43. pont.

66 Gál kontra Magyarország ügyben hozott ítélet, 44. pont.

67 Az előzetes letartóztatás gyakorlata, i. m., 51.

68 Az StPO 113. § (1) bekezdése a legfeljebb 6 hónapig terjedő szabadságvesztéssel fenyegetett büncselekmények esetében kizárja a kollúzió miatt a letartóztatás elrendelését. Erről részletesen lásd HERKE (2016): i. m., 147.

69 ELEK (2015): i. m., 47.

70 Nagy Gábor kontra Magyarország ügyben hozott ítélet, 30. pont. 
jellegü és igen súlyos (ötévi szabadságvesztésnél súlyosabban fenyegetett) büncselekmények esetén lehetővé tenni az emiatt elrendelt letartóztatást (kisebb súlyú büncselekmények esetén esetleg bünismétlöknél is)", ${ }^{71}$ továbbá kizárni azt, ha a büntetlen elöéletü, rendezett szociális körülmények között élö, vagyon elleni vagy közlekedési büncselekmény terheltjéröl van szó, vagy az eljárás tárgya gondatlan vagy mulasztásos büncselekmény. ${ }^{72}$ Szintén megfontolandó, hogy teljesen más jellegú bủncselekmény miatti vagy jóval korábbi elítélés ne szolgálhasson $d$ ) pontos előzetes letartóztatás okául. Ezzel szemben a különös vagy többszörös visszaesői minőség az EJEB esetjoga alapján is alappal hívható fel a tagállami bíróságok által a fogva tartás indokaként, ${ }^{73}$ érdemes lenne tehát a Be. vonatkozó rendelkezését is ehhez igazítani.

\subsection{Sztereotip és absztrakt indokolás}

Az előzetes letartóztatással kapcsolatos bírói döntésekkel szemben elvárás, hogy azok egyéniesítettek, valódi mérlegelést tartalmazók legyenek, a fogva tartás mellett és ellen szóló érveket érdemben értékeljék. Az Európa Tanács Miniszteri Bizottságának $R(80)$ 11. számú Ajánlása ${ }^{74} 8$. pontjában egyértelműen megköveteli, hogy a határozat a lehető legnagyobb pontossággal tartalmazza a megjelölt valós indokokat. Ezzel összhangban a Kúria 93. BK véleménye szerint az előzetes letartóztatás elrendelésére irányuló ügyészi indítványból és az ahhoz csatolt bizonyítékokból ki kell derülnie, hogy az ügyész a gyanúsított esetében az előzetes letartóztatás mely különös okát milyen adatok alapján látja fennállni, majd ugyanerröl a bíróságnak is számot kell adnia az elrendelő határozat indokolásában, kitérve a védelem ezzel kapcsolatos ténybeli és jogi érvelésére, álláspontjára is. A bíróságoknak rendkívüli gondossággal kell eljárniuk a különös okok vizsgálata során, így egyértelműen nem fogadható el az olyan indokolás, amely pusztán a rendelkező részben megállapított letartóztatási okot definiálja, de azt nem valószínüsíti egyedi tények alapján. Korábban sokkal inkább általános volt, hogy az ügyészi indítványok és az ezek nyomán született bírósági végzések sémaszerúek voltak, az általánosság szintjén mozogtak, az előzetes letartóztatás okait absztrakt módon határozták meg vagy sztereotip megállapításokat tartalmaztak. ${ }^{75} \mathrm{~A}$ védelmi indítványokban, fellebbezésekben kifejtett érvekre sokszor még csak reakció sem érkezett a bíróságok részéről. ${ }^{76} \mathrm{Az}$ utóbbi időben ezen a területen pozitív irányú elmozdulás történt, de a strasbourgi esetek

71 HERKe (2002): i. m., 298.

72 HERKE (2002): i. m., 299.

73 Például Clooth kontra Belgium ügy, 1998. március 5-i ítélet (ügyszám: 12718/87).

74 http://www.europatanacs.hu/pdf/CMRec(80)11.pdf (2017. 05. 01.).

75 Erröl részletesen lásd HolHós-KovÁcs Szilárd: Előzetes letartóztatás pro és kontra a bírósági eljárás és végzések tükrében. Bírák Lapja, 2011/1-2, 130-145; Közlemény Helyi Szakértői Csoport (Magyarország) találkozójáról. Fair Trials International-Magyar Helsinki Bizottság, 2013. február 21., https://www.fairtrials.org/ wp-content/uploads/Hungary-PTD-communique-Hungarian.pdf (2017. 05. 01.); KöszEg Ferenc: Bünözés, börtönnépesség, előzetes letartóztatás. Belügyi Szemle, 2011/4, 5-31.

76 Erről részletesen lásd Csomós Tamás: Átlátható kirendelt védői rendszert! Ügyvédek Lapja, 2014/2, 28-30. 
alapján azt is kijelenthetjük, hogy még mindig adódnak ezzel kapcsolatos problémák hazánkban. Ezt más vizsgálatok tapasztalatai szintén alátámasztják: az absztrakt körülményekre történő ügyészi hivatkozások elfogadása, a túl általános jellegü bírói indokolás és a védelem érveinek figyelmen kívül hagyása empirikus kutatási adatok alapján is problémát jelentenek. ${ }^{77}$

Az X. Y. kontra Magyarország ügyben hiába hivatkozott Magyarország arra, hogy az eljáró bíróságok az előzetes letartóztatást elrendelő és fenntartó döntéseiket az egyedi ügy adatai és a kérelmező személyes körülményei alapján hozták meg, az EJEB szerint a kérelmező által felhívott indokok érdemi figyelembevétele elmaradt, a bíróságok által felhívottak pedig nem elegendőek a kérelmező fogva tartásának igazolására. ${ }^{78} \mathrm{~A}$ Hagyó kontra Magyarország ügyben az EJEB úgy találta, hogy a kérelmező előzetes letartóztatását meghosszabbító bírósági döntések nem az összes vonatkozó tény elemzésén alapultak, a bíróságok „meglehetősen sztereotip” határozatai nem vizsgálták a tényekkel alátámasztott, lényeges kérelmezői érveket. ${ }^{79}$ A Baksza kontra Magyarország ügyben a Bíróság szintén úgy látta, hogy a határozatok indokolása többnyire „meglehetősen sztereotip” jellegű volt, és nélkülözte a hivatkozott konkrét veszélyeket valószínúsítő adatokat. ${ }^{80}$

A vizsgált esetek és az EJEB következetes gyakorlata alapján kijelenthető, hogy az előzetes letartóztatással kapcsolatos bírói határozatok nem tartalmazhatnak sztereotip megfogalmazásokat, indokolásuk nem lehet általános és absztrakt. ${ }^{81} \mathrm{Az}$ indokokat minden egyes esetben a konkrét tények vagy körülmények megjelölésével, az adott büncselekményre és a terhelttel kapcsolatos jellemzőkre figyelemmel kell meghatározni. Ezzel kapcsolatban másfél évtizede még teljesen indokoltan állapította meg Király Tibor: „A bíróságok gyakorlata azonban ma még messze van e követelményektöl. Ez alól sajnos a fellebbviteli fórumok sem mentesek." "22 Ez a kijelentés nem vonatkoztatható az ország egészére, a főváros például már korábban is sok tekintetben kedvezőbb képet mutatott az országos átlaghoz képest: „a Budapesten folytatott gyakorlat felel meg az országban leginkább annak a követelménynek, hogy a személyi szabadságot korlátozó kényszerintézkedés a lehetö legrövidebb ideig tartson, s mihelyt okafogyottá vált, az érintettet késedelem nélkül engedjék szabadon". ${ }^{83}$ Ahogyan akkor is, úgy ma is megyénként jelentősen eltérő gyakorlatról beszélhetünk, ${ }^{84}$ tehát ebben a tekintetben igen fontos lenne a további előrelépés, többek között az EJEB esetjogának maradéktalan figyelembevételével.

77 „Az iratkutatásban érintett mintában a bírói döntések 92,4\%-ában találtunk utalást az ügyész érveire, és csupán 50\%-ban a védelem érveire." Az előzetes letartóztatás gyakorlata, i. m., 7.

78 X. Y. kontra Magyarország ügyben hozott ítélet, 34-35. és 41-42. pont.

79 Hagyó kontra Magyarország ügyben hozott ítélet, 9. pont.

80 Baksza kontra Magyarország ügyben hozott ítélet, 38. pont. Ugyanezt állapította meg az EJEB az alábbi ügyekben: Hunvald kontra Magyarország ügyben hozott ítélet, 40. pont; Süveges kontra Magyarország ügyben hozott ítélet, 99. pont; Gál kontra Magyarország ügyben hozott ítélet, 43. pont.

81 Az elözetes letartóztatás gyakorlata, i. m., 12.

82 KIRÁlY Tibor: Büntetőeljárási jog. Osiris, Budapest, 2003, 288.

83 Rо́тн (2000): i. m., 124.

84 Védői jogok a bírósági eljárásban, i. m., 59. Az előzetes letartóztatással kapcsolatos gyakorlati tapasztalatok eltérősége tekintetében lásd Csomós Tamás: 2014 - az utolsó békeév? Ügyvédek Lapja, 2015/3, 39 és MAtusık Tamás: Gondolatok az előzetes letartóztatás hazai gyakorlatát ért kritikák kapcsán. Magyar Jog, 2015/5, 289. 


\section{A hatékony védelemhez való jog}

Balogh Jenő több mint száz esztendővel ezelőtt állapította meg: „Akármennyit hangoztatják is az elméleti szakférfiak az ügyfélegyenlöségnek kivánatos voltát, bizonyos, hogy korunknak állami közvádlójával és a védelemnek ez idő szerinti szervezete mellett ez az egyenlöség a gyakorlatban, a dolog lényegét tekintve egyáltalában nem érhető el." ${ }^{55}$ Sorai a mai napig érvényesek. Emiatt szükséges, hogy a védelem számára biztosított jogosítványokat a védő az eljárásban megfelelő színvonalon, hatékonyan és adekvát módon gyakorolja, függetlenül attól, hogy meghatalmazás vagy kirendelés alapján látja el feladatát. Az eljárás tisztességességének egyik eleme, hogy a terhelt védelemhez való joga hatékonyan érvényesüljön. ${ }^{86} \mathrm{Az}$ EJEB a hatékony védelemmel összefüggésben már korábban kimondta, hogy ezt a terhelti jogot a szabadságelvonástól kezdődően szükséges biztosítani, és a kihallgatás megkezdését megelőzően ez a jog már feltétlen érvényesítést kíván. ${ }^{87}$ Mindenképpen elörelépés, hogy a Be. tervezet és a Törvényjavaslat normaszövegében a terhelt hatékony védelemhez való joga jelenik meg, szemben a jelenleg sokszor csak formálisan megvalósuló védelemmel. ${ }^{88} \mathrm{Ez}$ azért is örvendetes fejlemény, mert a jelenlegi rendszer indokolt kritikájaként fogalmazható meg a védelemhez való jog „jogállami szempontból megnyugtatónak nehezen nevezhető” szabályozása. ${ }^{89}$ Ráadásul a hibás, gyenge védői tevékenység, az inkompetencia a téves elítélések, az ún. justizmordok egyik okát is jelenti. ${ }^{90} \mathrm{~A}$ kérdés teljes körü elemzése jelen tanulmány keretei között nem lehetséges, ezért kizárólag egyetlen aspektusát vizsgálom.

A hatékony védelem összetevői közül a kutatás szempontjából a kirendelt és a meghatalmazott védők munkája között régóta tapasztalható különbség bír relevanciával. Ezzel kapcsolatban az első átfogó ombudsmani vizsgálatra 1996-ban került sor, ${ }^{91}$ amely többek között megállapította, hogy a védelemhez való jog kirendelés esetén sokszor csupán formálisan érvényesül. Hasonló eredményre jutott 1998-1999ben lefolytatott empirikus kutatása alapján Fenyvesi Csaba is, aki szerint a meghatalmazott védők által nyújtott védelem magasabb színvonalú, mint a kirendelt védők tevékenysége. ${ }^{92} \mathrm{~A}$ helyzet a későbbiekben sem változott, egy évtizeddel később

85 BaLOGH Jenő: Magyar bünvádi eljárási jog. Grill Károly Cs. és Kir. Udvari Könyvkereskedése, Budapest, $1901,317$.

86 GÁcsI: i. m., 90.

87 Például Salduz kontra Törökország ügy, 2008. november 27-i ítélet (ügyszám: 36391/02), 52. pont és Dayanan kontra Törökország ügy, 2010. január 13-i ítélet (ügyszám: 7377/03), 32. pont. A Salduz-ügyről lásd Tóтн Mihály: A büntetőjog pillérei és korlátai. PTE ÁJK, Pécs, 2016, 199.

88 A Be. tervezete és a Törvényjavaslat azonosan: 3. § (1) A terheltnek a büntetőeljárás minden szakaszában joga van a hatékony védelemhez.

89 Ebben a körben elegendő csak a Be. 47. § (5) bekezdésében szabályozott helyettes védő jogintézményéről említést tenni, ami nyilvánvalóan pusztán a formális védelem biztosítására lehet alkalmas. Erről részletesen lásd KöHALMı László: A jogállami büntetőeljárás egy fontos kívánalma: a védelemhez való jog. In: Elek Balázs-Háger Tamás-Tóth Andrea Noémi (szerk.): Igazság, ideál és valóság. DE ÁJK Büntető Eljárásjogi Tanszék, Debrecen, 2014, 261-262.

90 FEnYvesı Csaba: A kriminalisztika tendenciái. Dialóg Campus, Budapest-Pécs, 2014, 172.

91 Jelentés az OBH 6564/1996. számú vizsgálatáról.

92 FenYvesı Csaba: A védőügyvéd. Dialóg Campus, Budapest-Pécs, 2002, 118. 
Tóth Mihály a következőket állapította meg: „Amire azonban még ma sem találtunk megoldást, az a kirendelt és meghatalmazott védők munkájának színvonala, intenzitása és hatékonysága közötti jól érzékelhetö különbség. Egyes mértéktartó becslések szerint is meghatalmazott védővel rendelkező gyanúsítottaknak kb. ötször annyi esélyük van megfelelő védekezés kialakitására, elöterjesztésére és elfogadtatására, mint azoknak, akiknek a törvény kötelező elöirása folytán a hatóság rendel ki védőt." ${ }^{93}$

A probléma azóta is fennáll, különösen arra figyelemmel, hogy a védö jelenléte a nyomozás során, így az előzetes letartóztatással kapcsolatos üléseken opcionális, így a kirendelt védők a gyakorlatban ritkán jelennek meg ezeken, ha pedig jelen vannak, akkor az aktivitásuk szintje többnyire alacsony. $E$ tényezők együttesen aláássák a védelem hatékonyságát. ${ }^{94} \mathrm{Az}$ alapvető jogok biztosának AJB-3107/2012. számú ügyben készített jelentése többek között az Országos Rendör-fökapitányság és a megyei ügyvédi kamarák álláspontját is tartalmazza. A jelentésben foglaltak szerint a rendőrségi tapasztalatok azt mutatták, hogy a kirendelt védők hatékonysága, tevékenységük színvonala jobbára alatta maradt a meghatalmazott védőkének. ${ }^{95} \mathrm{Az}$ ügyvédi kamarák a probléma forrásaként azt jelölték meg, hogy a nyomozó hatóságok általában ugyanazon ügyvédeket rendelik ki, akik egzisztenciális okokból vagy más megfontolások alapján kerülik a kirendelő hatósággal való konfliktust, holott ez az érdemi védekezéssel szükségszerüen együtt jár. $A$ helyzet tehát alapvetően oda vezethető vissza, hogy az a hatóság választ védőt a terhelt számára, mégpedig teljesen szabadon, amely előtt az eljárás folyamatban van, tehát eljárási helyzeténél fogva nem érdekelt az érdemi védekezési tevékenység kifejtésében..$^{96}$ Dicső Gábor arra is rámutat, hogy a kirendelt védők érdekeivel a büntetőeljárás eredményes mihamarabbi lezárása sem mindig találkozik, ${ }^{97}$ nyilván anyagi megfontolásokból.

További probléma, hogy a kirendelések elosztása nem arányos és nem átlátható, ami sérti az ügyvédek közötti esélyegyenlőséget és a védelemhez füződő jogi garanciákat. Ehhez a problémakörhöz kapcsolódik az EJEB 2016 novemberében hozott ítélete, ${ }^{98}$ amelyben megállapította, hogy a magyar állam megsértette a Magyar Helsinki Bizottság véleménynyilvánításhoz füződő jogát, amikor a rendőrség megtagadta a kirendelt védők nevének és az általuk vitt ügyek számának kiadását a szervezet számára. Az ügy előzménye, hogy a Magyar Helsinki Bizottság 2009-ben 28 rendőrkapitányságtól kérte ki az azt megelőző évben kirendelt védők nevét és kirendeléseik számát. A kapott adatok egyértelműen igazolták a szakirodalomban kifogásolt kirendelési gyakorlatot: voltak olyan ügyvédek, akik évi több száz kirende-

93 Тоттн Mihály: Gondolatok egy a védelem hatékonyságának javítását célzó kísérlet kapcsán. In: Nagy Ferenc (szerk.): Ad futuram memoriam. Tanulmányok Cséka Ervin 85. születésnapjának tiszteletére. Pólay Elemér Alapítvány, Szeged, 2007, 158.

94 Az előzetes letartóztatás gyakorlata, i. m., 7.

95 Az alapvető jogok biztosának az AJB-3107/2012. számú ügyben készített jelentése, 30.

96 KÁDÁr András Kristóf-NovoszÁDEK Nóra-Selel Adrienn: Ki rendelt itt védőt? Magyar Helsinki Bizottság, Budapest, 2012, 11.

97 Dıcső Gábor: Egyeztetés a büntetőeljárásban, avagy „alku” a büntetőperben. In: Elek Balázs-Miskolczi Barna (szerk.): Úton a bírói meggyőződés felé. Printart-Press, Debrecen, 2015, 89.

98 Magyar Helsinki Bizottság kontra Magyarország ügy, 2016. november 8-i ítélet (ügyszám: 18030/11). 
lést kaptak, és olyan kapitányság is, ahol az ügyek több mint $80 \%$-ában ugyanazt a védőt rendelték ki. A strasbourgi eljárás amiatt indult, mert bár tizenhét rendőrkapitányság kiadta a kért adatokat, az adatszolgáltatást megtagadó kapitányságok esetében a Legfelsőbb Bíróság (ma Kúria) háromszor is úgy döntött, hogy a rendőrség által kirendelt, az állam által fizetett védők neve és az általuk vitt ügyek száma nem nyilvános adat, így azokat nem kell kiadni a szervezetnek. Ezeknek az adatoknak a birtokában már tényszerűen igazolhatók a korábbi felvetések, és a kirendelési gyakorlat átalakítása nem halogatható tovább. A magam részéröl örömteli fejleménynek tartom, hogy a Törvényjavaslat 46 . $§(1)$ bekezdése értelmében a kirendelés alapján védőként eljáró ügyvéd kijelölése a jövőben az ügyvédi kamarák feladatává válik.

A hatékony védelemhez való jog további fontos kérdése a védői jelenlét szabályozása az eljárási cselekményeknél. A távolmaradás, az esetleges felkészületlenség nem kizárólag a kirendelt védők hanyagságával vagy nemtörődömségével magyarázható, hanem következik a hatóságok nem megfelelő értesítési gyakorlatából is. Ezzel kapcsolatban kiemelendő az Alkotmánybíróság 8/2013. (III. 1.) AB határozata, ${ }^{99}$ amely szerint számos esetben fordul elő, hogy a nyomozó hatóság az éjjeli órákban bünügyi őrizetbe vett és kihallgatott terheltek részére a kirendelt védőt telefax útján úgy értesíti, hogy a védő nyilvánvalóan csak a következő munkanap reggeli óráiban, már a terhelti kihallgatás lebonyolítása után értesül az eljárási cselekményről. ${ }^{100} \mathrm{Ez}$ sajnos nem kizárólag a kihallgatásokra igaz, hanem például az előzetes letartóztatással kapcsolatos ülésröl történő értesítésre is. Fontos lenne ezért törvényben elöírni, hogy az eljárási cselekményekröl, így az elözetes letartóztatással kapcsolatos ülésről olyan időpontban történjen az értesítés, amely reálisan lehetővé teszi a védő számára az azon való részvételt.

Elörelépés a jelenlegi helyzethez képest, hogy a Be. tervezet 463 . § (3) bekezdésével azonosan a Törvényjavaslat 470 . $§(3)$ bekezdése alapján az ügyészség az ügyiratok megismerését a védekezésre való felkészüléshez szükséges időben és módon - legkésőbb egy órával az ülés megkezdése előtt - köteles a terhelt és a védő számára biztosítani. Az empirikus kutatási adatok szerint jelenleg a felkészülési idő sok esetben kevesebb, mint 30 perc. ${ }^{101}$ Szükséges azonban rámutatni, hogy az egyórás időintervallum sem teszi lehetővé a védelem számára, hogy az ügyészi indítványban vagy az ahhoz csatolt nyomozási iratokban foglaltakkal szemben bizonyítékot szerezzen és csatoljon be az előzetes letartóztatásról döntő bírónak, tehát a Törvényjavaslat a jelenleginél ugyan hatékonyabb, de nem feltétlenül valóban hatékony védekezésre nyújt lehetőséget.

\section{Mérleg: elöremutató lépések és fennmaradó hiányosságok}

Az új büntetőeljárási törvény kodifikációja során egyértelmü szempont volt, hogy a jogszabály tekintettel legyen többek között az Egyezmény rendelkezéseire és az

\footnotetext{
$99 \mathrm{ABH} 2013,312$.

100 A kérdéskört empirikus kutatás alapján részletesen elemzi GÁcsı: i. m., 79-84.

101 Az előzetes letartóztatás gyakorlata, i. m., 38.
} 
EJEB gyakorlatára. ${ }^{102} \mathrm{~A}$ letartóztatás és az alternatív kényszerintézkedések vonatkozásában a Be. tervezet és a Törvényjavaslat jelentős eltéréseket tartalmaz, utóbbit több tekintetben visszalépésnek tartom. A fentiekben összegzett kutatás alapján a következőkre szükséges rámutatni:

Az EJEB több határozatában leszögezte, hogy az Egyezmény 5. cikk 3. bekezdése nem értelmezhető úgy, hogy a fogvatartott egészségi állapotára figyelemmel a szabadlábra helyezése kötelező a nemzeti hatóságok részéröl. Ezt a körülményt azonban vizsgálni szükséges az idő múlásával együtt annak kontextusában, hogy a letartóztatás valóban az észszerü időn belül történő bíróság elé állítás célját szolgálja-e vagy sem. Ilyen módon dönthető el, hogy szükséges-e a további fogva tartás vagy sem. A vonatkozó határozatok alapján az a tendencia rajzolódik ki, hogy az idő múlásával a fogvatartott romló egészségi állapota egyre kevésbé indokolja az előzetes letartóztatás szükségességét, és indokolttá teszi alternatív kényszerintézkedések alkalmazását. A hatályos törvényi szempontrendszer alapján azonban a házi őrizetnél nem, csak a lakhelyelhagyási tilalomnál játszanak szerepet a terhelt személyi és családi körülményei ${ }^{103}$ Erre tekintettel helyes és indokolt változás a Be. tervezet 270 . $§(1)$ bekezdése alapján, hogy a letartóztatás helyett alkalmazható bűnügyi felügyelet elrendelésekor - többek között - figyelemmel kell lenni a terhelt személyi és családi körülményeire, különösen az egészségi állapotára, idős korára. A Törvényjavaslat 277. § (4) bekezdésének c) pontja ezt a példálózó jellegü felsorolást mellőzi, a miniszteri indokolás pedig nem ad iránymutatást a kérdésben, de remélhetőleg a vizsgálandó szempontok a tervezetben kiemelt körülményekre is ki fognak terjedni.

A Nagy Gábor kontra Magyarország ügyben további megfontolásra alkalmas megállapítást tett az EJEB, amikor kimondta: „A fogvatartás ellen benyújtott kérelmek vonatkozásában a bíró általi meghallgatáshoz való jogot ésszerü időközönként gyakorolni kell... A bíróság nincs meggyőződve arról, hogy fogvatartásának igazoltságával kapcsolatosan a kérelmezőt ésszerü időközönként meghallgatták... Különösen a négy hónap körüli időszak nem tekinthető ésszerü időköznek." ${ }^{104} \mathrm{~A}$ Galambos kontra Magyarország ügyben a Bíróság ezzel összhangban rögzítette, hogy a döntően írásbeli eljárás nem ad megfelelö lehetőséget a védelem számára, hogy hatékonyan vitathassa az ügyészi indítványban foglalt érveket, vagy elöterjeszthesse ezzel kapcsolatos bizonyítékait. ${ }^{105}$ A Bandur kontra Magyarország ügyben szintén kifogásolta az EJEB, hogy a kérelmezőt a három hónapos fogva tartása során csupán egyetlen alkalommal, a kényszerintézkedés elrendelésekor hallgatta meg a bíróság, egyebekben bírósági meghallgatás nélkül történt az előzetes letartóztatás meghosszabbítása úgy, hogy az ügyészi indítványt a bíróság döntését megelőzően a védelemnek nem kézbesítették. A Bíróság hangsúlyozta, hogy a személyi szabad-

\footnotetext{
102 Mıskolczı Barna: Az új büntetőeljárás kodifikációs irányelvei. In: Elek Balázs-Miskolczi Barna (szerk.): Úton a bírói meggyőződés felé. Printart-Press, Debrecen, 2015, 31.

103 Holé-Kadlót: i. m., 558.

104 Nagy Gábor kontra Magyarország ügyben hozott ítélet, 45. és 48. pont.

105 Galambos kontra Magyarország ügyben hozott ítélet, 35. pont.
} 
ság elvonására csak kontradiktórius eljárásban kerülhet sor, amelyet a nemzeti jog többféle módon biztosíthat, a szóban forgó ügyben azonban ez a követelmény nem teljesült. ${ }^{106}$

Két probléma merül fel tehát: a bírói meghallgatások alacsony száma és az ügyészi indítványokkal kapcsolatos védelmi érvek bevárásának elmaradása a bírói döntéshozatalkor, amely nyilvánvalóan összefüggésben van azzal, hogy a védelem részére az indítványt mikor kézbesítik. Jelenleg a Be. 210. §-a alapján az elrendelés és a hat hónapot meghaladó hosszabbítás tartozik ülésre, egyebekben csak akkor kell azt tartani, ha az indítványban a korábbi határozathoz képest a meghosszabbítás okaként új körülményre hivatkoztak. Hangsúlyozandó, hogy ez a szabály nem vonatkozik a védelem által az előzetes letartóztatás megszüntetése iránt benyújtott indítványra, akár tartalmaz az új körülményeket, akár nem. Ebben nincs változás a Be. tervezet 459 . $\S(1)$ bekezdése és a Törvényjavaslat 466 . $§(1)$ bekezdése alapján sem.

Az elözetes letartóztatás hazai gyakorlatában tehát egyáltalán nem példa nélküli, sőt inkább általános tapasztalat, hogy a Nagy Gábor kontra Magyarország ügyben kifogásolt négy hónapos időtartamig nem kerül sor a terhelt bírói meghallgatására, kizárólag írásbeli eljárás keretében történik a kényszerintézkedés meghosszabbítása. Ennek során pedig szintén előfordul, hogy a bíróság nem várja be a védelemnek az ügyészi indítvánnyal kapcsolatos észrevételeit, még akkor sem, ha erre egyébként elegendő idő állna rendelkezésre. A strasbourgi elvárásokra tekintettel szükséges lenne a bírói meghallgatás rövidebb időközönkénti szabályozása, továbbá a védelem észrevételeinek megtételére határidő biztosítása, amelynek a terhelt vagy védő általi elmulasztása természetesen nem akadályozná a bírói döntéshozatalt. További problémát jelenthet, hogy a letartóztatással kapcsolatos fellebbezés elbírálása iratok alapján történik, vagyis a jogorvoslat során eljáró bíróság jelenleg soha nem találkozik személyesen a terhelttel. Itt is szükséges lenne biztosítani az ülés tartásának lehetöségét. ${ }^{107}$ A Törvényjavaslat 480 . $§(3)$ bekezdése viszont csak a letartóztatás elrendelésére irányuló inditvány elutasitása esetén teszi lehetővé a jogorvoslati nyilatkozat megtételével egyidejüleg a fellebbezés ülésen történő elbírálásának indítványozását. A 481. § (4) bekezdés második mondata szerint a törvényszék erre irányuló indítvány hiányában is tarthat ülést, de nem egyértelmü, hogy ez a 480 . § (3) bekezdésére történő visszautalás miatt csak az abban foglalt esetben vagy attól függetlenül is lehetséges. Mindenképpen hiányzik azonban annak biztosítása, hogy a letartóztatás elrendeléséve/ szemben benyújtott jogorvoslat erre irányuló indítvány alapján ülésen kerüljön elbírálásra.

Az alternatív kényszerintézkedések alkalmazását volt hivatott előmozdítani a Be. tervezet azon rendelkezése, miszerint az óvadék minden olyan előzetes letartóztatási ok esetén helyettesítő kényszerintézkedéssé válik, amely valamilyen megalapozott veszélyt foglal magában. Ráadásul az óvadék tárgya már nemcsak készpénz, hanem ingatlan, ingóság és értékpapír is lehetett volna. A változtatás nem titkolt

106 Bandur kontra Magyarország ügyben hozott ítélet, 79-80. pont.

107 Erről részletesen lásd $A z$ előzetes letartóztatás gyakorlata, i. m., 8. és 43. 
célja a letartóztatások számának visszaszorítása lett volna. ${ }^{108}$ Ezzel a megoldással, továbbá a bünügyi felügyelettel kapcsolatos tervezett szabályozással megítélésem szerint a bíróságok lehetőségei tovább bővültek volna a személyi szabadságot kevésbé korlátozó kényszerintézkedések igénybevételére. Sajnálatos módon a Törvényjavaslat 282. §-a az óvadékot a bünügyi felügyelet és a távoltartás magatartási szabályait biztosító intézkedéssé redukálta. Ezzel némileg ellentétben a 285. § (1) bekezdés $c$ ) pontja a bünügyi felügyelet és a távoltartás megszüntetését is lehetővé teszi óvadék ellenében. Az óvadék tárgya a Törvényjavaslat szerint továbbra is csak pénz lehet. Megítélésem szerint a Be. tervezet szabályozása egyértelmübb, logikusabb volt, mint a Törvényjavaslaté, viszont üdvözlendő változás, hogy valamennyi letartóztatási ok esetében lehetővé válik az óvadék felajánlása.

Az előzetes letartóztatás feltételeit a Be. tervezethez képest a Törvényjavaslat megváltoztatta. ${ }^{109}$ Megítélésem szerint a Törvényjavaslat 277 . $\S(4)$ bekezdés $b$ ) pontja ellentétben áll a 166/2011. (XII. 20.) AB határozatban rögzítettekkel, mert azt írja elö, hogy a letartóztatás elrendelésekor a nyomozási bírónak figyelemmel kell lennie a nyomozás érdekeire. A nyomozási bíró a német büntető perrendtartásból átvett jogintézmény, amelynek fő funkciója az eljárási garanciák érvényre juttatása és ennek keretében az alapjogvédelem biztosítása a nyomozási szakaszban. Az, hogy döntése során bármilyen nyomozástaktikai megfontolásra figyelemmel legyen, a hivatkozott $A B$ határozat alapján egyértelmúen alaptörvény-ellenes és nemzetközi szerződésbe ütköző. ${ }^{110}$ Arra, hogy ez a (Be. tervezetben még nem szereplö) erösen kifogásolható rendelkezés milyen érdekek miatt került a szövegbe, a miniszteri indokolás nem ad magyarázatot.

Összességében elmondható, hogy a korábbi időszakban nemzeti jogunk nemhogy magasabb követelményrendszert nem alakított ki az emberi jogok védelmére a strasbourgi gyakorlathoz képest, hanem több vonatkozásban hosszú időn keresztül kifejezetten elmaradt attól. A kutatásom alapján azonban úgy vélem, az utóbbi időben jelentős elörelépések történtek a Be. strasbourgi esetjognak megfelelő átalakítása terén, és ebben további mérföldkő lehet az új büntetőeljárási kódex. Amennyiben a Be. tervezet jelen tanulmányban ismertetett elemei jogszabállyá válnak, úgy a továbbiakban legfeljebb csak "finomhangolásra” lesz szükség. A Törvényjavaslattal összefüggésben az előzőekben kifejtettek alapján már nem vagyok ilyen bizakodó.

108 Mıskolczı Barna: Az új Be. föbb vonásairól (1.). Ügyvédvilág, 2016/2, 24.

109 A törvényjavaslat vonatkozó része:

277. § (4) Letartóztatás a terhelt jelenlétének biztosítása, a bizonyítás megnehezítésének vagy meghiúsításának megakadályozása, illetve a bünismétlés megakadályozása érdekében rendelhető el, ha különösen

a) a büncselekmény jellegére,

b) a nyomozás állására és érdekeire,

c) a terhelt személyi és családi körülményeire,

d) a terhelt és a büntetőeljárásban részt vevő vagy más személy viszonyára,

e) a terhelt büntetőeljárás előtt és az eljárás során tanúsított magatartására tekintettel a személyi szabadságot érintő bírói engedélyes kényszerintézkedéssel elérni kívánt cél távoltartással, illetve bünügyi felügyelettel nem biztosítható.

110 Az idézett határozatban az Alkotmánybíróság kimondta, hogy ha „a nyomozási bíró eljárásában köteles figyelemmel lenni a nyomozó hatóság és az ügyész speciális, kizárólag a nyomozás során érvényesíthető nyomozástaktikai szempontjaira”, az alkotmányellenes és egyben nemzetközi szerződésbe is ütközik. 
Pedig ahogy azt a kutatásom igazolta, sok esetben önmagában még a normaszöveg fejlődése sem elégséges az érdemi változáshoz, a mindennapi gyakorlatban a büntetőeljárás szereplőinek részéről is szemléletváltás kell ahhoz, hogy az emberi jogok védelme a lehető legteljesebb mértékben érvényesüljön.

\begin{abstract}
The case law of the European Court of Human Rights and the European Convention on Human Rights set the minimum level for the protection of fundamental rights that has to be guaranteed by all contracting parties, although national laws can establish higher standards. Point II of the General Explanations of Bill No. T/13972 on the new Act on Criminal Procedure states that "Meeting the requirements of the Fundamental Law of Hungary and the obligations of international law and EU law obviously mean a safeguarding minimum." In Hungary the case law of the ECtHR is reflected more and more both in the judgements of Hungarian courts and in the guidelines of higher courts but the difficulties of establishing interpretations in harmony with ECtHR case law are common. The paper analyses the judgments of the ECtHR in Hungarian cases between 2013 and 2016 related to pre-trial detention, effective defence and the circumstances of restraint.
\end{abstract}

